\title{
Distributing Enterprise Value to Stakeholders in the Range of Sustainable Development on the Basis of the Energy Industry in Poland
}

\author{
Sylwia Lorenc* and Arkadiusz Kustra (])
}

check for updates

Citation: Lorenc, S.; Kustra, A Distributing Enterprise Value to Stakeholders in the Range of Sustainable Development on the Basis of the Energy Industry in Poland. Sustainability 2021, 13, 2130. https://doi.org/10.3390/su13042130

Academic Editor: Agnieszka Wiśniewska

Received: 2 February 2021

Accepted: 15 February 2021

Published: 17 February 2021

Publisher's Note: MDPI stays neutral with regard to jurisdictional claims in published maps and institutional affiliations.

Copyright: (c) 2021 by the authors. Licensee MDPI, Basel, Switzerland. This article is an open access article distributed under the terms and conditions of the Creative Commons Attribution (CC BY) license (https:/ / creativecommons.org/licenses/by/ $4.0 /)$.
Department of Economy and Management in Industry, AGH University of Science and Technology, 30-059 Kraków, Poland; kustra@agh.edu.pl

* Correspondence: slorenc@agh.edu.pl

\begin{abstract}
The aim of this paper is to analyse and compare the process of distributing value to stakeholders in energy industry enterprises in the range of sustainable transition. The analysis focuses on the four largest energy companies in Poland: ENEA Group, ENERGA Group, PGE Group and TAURON Polish Energy. Directions of value distribution in these companies have been presented for the years 2009-2018. The paper identifies the main groups of stakeholders of the above companies, i.e., owners, employees, suppliers, capital providers, the state budget and the budgets of local government units. The value dedicated to these stakeholders was estimated based on the free cash flow (FCF) methodology. According to the presented analysis, in the years 2009-2018, the energy industry in Poland realised a total of 236.2 billion PLN for selected stakeholders. PGE Group generated the most financial benefits, providing nearly 120 billion PLN. The smallest value was realised by ENERGA Group in the amount of over 28 billion PLN. Identification of added value according to the proposed methodology may support the process of making decisions related to the continuation or cessation of energy-related activities in the light of continued or lost potential stakeholder benefits.
\end{abstract}

Keywords: sustainable development; sustainable value; economic value added; energy market; energy economics; energy transition; stakeholders; value distribution

\section{Introduction}

Bearing in mind the current economic situation in Poland and in the world, the approach of perceiving company value in terms of the maximisation of benefits for the shareholders does not seem to be very up to date [1]. Current market conditions force enterprises to seek new ideas in order to gain competitive advantage and increase their value $[2,3]$. Departure from traditional value measurement concepts, drawing on the shareholder theory, resulted in greater attention being paid to enterprise stakeholders, who directly contribute to the process of shaping the company's economic success $[4,5]$. In the evolution of the ideas of sustainable development (SD) and corporate social responsibility (CSR), one can observe a growing interest in building sustainable value, which is based on satisfying the needs of all stakeholders in the organisation (the stakeholder theory) [6]. Thus, it is emphasised that enterprises need not only to adapt to legal requirements in this respect but also to carry out additional activities to invest in human capital, environmental protection and relations with their stakeholders [7-9].

Based on the analysis of the research literature on enterprise value, it is possible to identify a number of tools for measuring an enterprise's value for its owners [10-12]. However, among the solutions proposed by the authors, there is a too narrow range of effective tools for measuring sustainable value for stakeholders [13-15].

The main purpose of the article is to present the concept of value distribution for stakeholders of enterprises operating in a specific market environment and strongly influencing it. The need for such analyses and having such comprehensive knowledge is due to 
the strategic management of the enterprise, consistent with sustainable development and corporate social responsibility. Previous studies have focused primarily on the profitability of operations for owners and other capital donors. Their interests were decisive for the effectiveness and continuation of activity in the long term. It should be noted that analyses of corporate financial models and stakeholder inclusion are conducted and based on the so-called added value. It takes into account accrual income and costs which result in financial results. In this paper, the authors decided to extend the conducted analyses and take into account the financial flows that adjust the accrual values for resources related to assets and liabilities. Thus, they give a complete picture of the money flow for stakeholders.

The change in management paradigms and the recent phenomena related to the COVID-19 pandemic have highlighted the inclusion of a wider group of stakeholders in the enterprises. On the other hand, identifying the benefits for each of them, it allows to determine the impact and the scale of advantages from the activity of specific economic entities. This is particularly important in the case of enterprises with a strong impact on a wide range of stakeholders, with a significant share of the state treasury in the ownership structure.

Such entities are usually of strategic nature for the economy of a country or region. Their analysis and considerations must take into account the complex economic, social and environmental impacts for stakeholders. The analysis of research problems presented in this paper were carried out on the example of the energy industry in Poland, where four state-owned energy corporates dominate the whole business. They affect many groups of interests, constituting strategic resources of the country economy. These companies meet all requirements, where a sustainable development and policy of generating benefits to stakeholders determine the strategic management model, which is worth analysing and filling the research gap.

\section{Literature Review: A Conceptual Framework}

In the 1990s, all measurement models, methods and tools were geared to estimating benefits for owners [16,17]. Nowadays, when the goals and strategies of businesses have been reoriented [18] towards creating a sustainable enterprise [19], the priority of most organisations is to create long-term value for all its stakeholders: shareholders, employees, customers, business partners, local government units, providers of capital, society and others, in line with the example set by the Master of Business Administration (MBA) oath: to "create value responsibly and ethically," composed by graduates of the Harvard Business School [20].

According to Freeman [21], for the first time, the term stakeholder was used in 1963 in a document worked out by the Stanford Research Institute for the purposes of identifying the groups of entities to which the owners of each enterprise should be responsible and without whose support the organisation would cease to exist. Harrison, however, indicates an earlier work-Silbert from 1952 [22]. Many works referring to this idea have been published since its first publication. However, there are so many different interpretations of basic stakeholder theory that its development has been difficult [23].

According to Post, Preston and Sachs [24], effective stakeholder management, i.e., managing relations with stakeholders for mutual benefit, is a key condition for corporate success.

The importance of the role of stakeholders was also emphasised by Wheeler and Sillanpää [25], who pointed to the business case for developing loyal relationships with customers, employees, shareholders and other stakeholders.

Zakhem, Palmer and Stoll [26] claim that the stakeholder theory goes beyond the conventional notion that the shareholders are the main group to whom corporate managers owe responsibility. The stakeholder model assumes a much broader view on the social and economic goals of the organisation, arguing the need to be responsible also to other groups in the business environment.

Interest groups that directly or indirectly affect an enterprise raise different expectations with respect to this enterprise, often contradictory to each other [27]. The mutual 
relationship between the enterprise and its stakeholders may take the form of interests, rights to the business entity or shares in this entity. Each interested group strives to maximise the benefits it reaps, especially financial ones. Marcinkowska [28] claims that according to contract theory, an enterprise is a bundle of contracts, under which particular groups of stakeholders provide it with specific resources (skills, products and services, cash and capital) and, in return, receive real benefits in the form of dividends, remuneration, interest, products and services, taxes and cash subsidies.

Darškuviene and Bendoraitienè [29] argue that the owners' expectations are centred around a high rate of return on invested capital, which would compensate for the risk incurred, and around rising share prices, which determine an increase in the company's market value. For employees and managers, who invest their energy, effort, time and attention in the company [30], the most important is the remuneration they earn, promotion opportunities and the prospect of fulfilling their professional aspirations. Harrison and Wicks [31] claim that suppliers and strategic partners focus on building sustainable, longterm commercial contracts that will ensure their financial security, and customers expect high-quality products and services, accompanied by a wide range of available products and competitive prices. Institutions financing business operations of a company will be interested in the timely settlement of the company's liabilities.

Olkkonen [32] shows that the importance of a certain enterprise for the economy and interests of the state is also not without an influence. Authorities, both at the local and central level, expect high revenues from tax liabilities as well as development of the region through employment growth. According to Theodor [33], this fact is of great importance for local communities, whose members are provided with jobs and therefore can take advantage of social, healthcare, educational and cultural benefits.

The main task of the enterprise is to identify individual interest groups and their expectations, and then to prioritise them, and prioritisation determines whether these needs will be met or not [34].

However, the expectations of particular stakeholders of the enterprise are not exclusively limited to financial categories. As part of the concept of a triple bottom line [5], it is more and more often highlighted that efficiency needs to be ensured in three areas: The economic, social and environmental areas [35]. At the same time, the importance of non-financial benefits is emphasised: these include contentment (with work, products, services, business relations), satisfaction (with promotion, economic development), quality (of goods, working conditions, social life), usefulness (of a product, volunteering, social campaigns) and safety (of life, work, the region) [36]. The key is to determine what is important to stakeholders (both in the financial and non-financial perspective) and provide them with the kind of utility they see as beneficial [37].

The main task of the company in this field is, first and foremost, to identify the main stakeholders and determine their individual expectations. This is particularly important in the case of interest groups on which the organisation has a strong impact and those that exert a significant impact on the enterprise. As Freeman believes [5], the survival and development of the company depends chiefly on them.

Maintaining strong relationships with stakeholders contributes to value creation because these relationships are a source of competitive advantage with a significant ability to improve business performance $[5,31,38]$.

According to Popescu and Popescu [39], entities around the world no longer focus solely on profit, efficiency and financial results, but are more willing to engage in activities for the benefit of the community and the environment. Business ethics plays a fundamental role in all organisations, especially in ensuring long-term sustainability. For this reason, correlations between sustainable development, corporate social responsibility, corporate governance and financial and non-financial performance of enterprises are increasingly noticeable. According to Reference [40], corporate governance is a key element in improving economic efficiency, supporting growth and enhancing investor confidence, especially in 
the context of the energy market, which is currently facing various challenges. Undoubtedly, green and sustainable management is becoming one of them for these companies.

In the case of fuel and energy enterprises, due to the specificity of their operations, sustainable management based on creating value for stakeholders is of great importance. Sfora and Kamiński [41] indicate that the complicated structure of these companies, made of elements linked by numerous organisational, economic, financial, technical and technological conditions and relations, affects the shape of the strategy and business model such companies adopt. Suwała [42] raised the issue of adjusting the coal industry to the conditions of sustainable development. For this reason, as studied by Bluszcz and Manowska [43], the strategy for building energy companies' value is nowadays more and more often pursued with the use of sustainable development tools. The impact of the energy industry operating in accordance with the principles of sustainable development can also be observed in the research, including by Bradbrook, Hemmersbach, Lebert, Ottinger and Wang [44], Kanagawa and Nakata [45], Meyar-Naimi and Vaez-Zadeh [46], Wang, Nathwani and $\mathrm{Wu}$ [47] and Tiba and Omri [48].

Bradbrook, Hemmersbach, Lebert, Ottinger and Wang [44] point to the strong need to increase the efficiency of energy use and the need to move away from fossil fuel dependence in favour of renewable energy sources. Kanagawa and Nakata [45] present the relationship between access to electricity and the socio-economic condition of rural developing countries. Meyar-Naimi and Vaez-Zadeh [46] developed a methodology review and proposed an operational framework to support policymakers and analysts towards a sustainable energy policy. Wang, Nathwani and $\mathrm{Wu}$ [47] emphasise that the shape of international energy policy is changing rapidly, research into energy policy has transcended the boundaries of the energy economy and to a greater extent covers climate change, environmental protection and environmental impact. In addition, it indicates the need to limit the environmental impact in order to achieve sustainable results. Tiba and Omri [48] argue that understanding the relationship between economic growth, energy consumption and the environment is a key to understanding the current energy and environmental policy, is the cornerstone of a new view of energy and environmental policy. This relationship is fundamental to shaping reasonable economic policies with their goals in the field of environmental and energy policy.

Creating company value is a key element of the business strategy $[17,19]$. However, in the case of energy companies, this process is slightly more complicated than in the case of companies from other sectors. This is in particular due to the number of existing stakeholder groups and the peculiarity of this industry, which poses a special challenge to the implementation of the concept of sustainable management [49]. In order to implement and adhere to the principles governing the key areas of sustainable development, according to Lorenc and Sorokina [50], it is necessary to see these principles not through the prism of necessary expenses but as effective tools for achieving the enterprise's primary goal, i.e., value creation. In addition, the significant impact of the sector on the economic, social and environmental areas means that sustainable energy industry and continuity of economic processes are directly related to the need to build the country's fuel and energy security, based on constant and sufficient access to optimal quality fuels [43,51]. On the local ground, the draft of Poland's raw materials policy [52] sets out the possibilities of integrating the interests of both the state and its citizens. It focuses on the rational management of natural resources as well as establishing conditions for investments in sustainable development areas, taking account of the current, constantly updated state of knowledge and development forecasts. This is supposed to contribute to a stronger position of the Republic of Poland in the international arena.

\section{Materials and Methods}

This section presents the stakeholder value model and its assumptions. It was decided to focus on a cash approach based on free cash flow (FCF). The paper attempts to estimate the financial benefits reaching the individual beneficiaries of the enterprise using the 
authorial concept of estimating the created value. The article adopts a comparative method of analysis in order to better understand the similarities and differences in the presented enterprises.

Due to the growing importance of public awareness and the concept of sustainable enterprise management, it has become necessary to extend company reporting to issues associated with creating value for stakeholders and possibilities of ensuring its sustainable growth. Hence, there is a need to develop a report (model) that will make it possible to determine the structure of value distribution and, by indicating the investment potential, provide a real reflection of the financial benefits (understood as cash flow) that particular groups of beneficiaries receive.

In the source literature, the role of cash flow reporting is increasingly emphasised as one of the basic sources of information in the decision-making process regarding the enterprise's activities [53-56]. However, until now, cash flow has not been used in business practice as a tool for measuring sustainable value, i.e., value for the enterprise's stakeholders. This was a prompt for the creation of the aforementioned model, for the purposes of which the authors have presented their own concept of free cash flow from value added (FCF VA). It was assumed that FCF VA is the sum of cash flow for the selected groups of stakeholders. For the purposes of the analysis, six main groups of enterprise stakeholders were selected; according to the authors, these are one of the largest recipients of financial benefits generated by the companies. The study comprised estimation of cash flow for owners (free cash flow to equity, FCFE), workers (free cash flow to workers, FCFW), capital providers (free cash flow to debts, FCFD), suppliers (free cash flow to suppliers, FCFS), local governments (free cash flow to municipal administration, FCFM) and the state budget (free cash flow to state, FCFSt). The stakeholder value measurement model is grounded on cash flows based on operating and financial costs. Figure 1 presents the above model, evaluating the profits received by the selected stakeholders, along with the elements that underlay its creation.

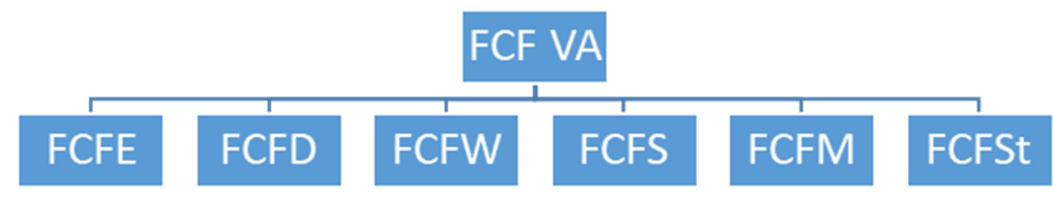

Figure 1. Cash flow from value added to stakeholders (Source: own work). where: FCF VA = free cash flow from value added, FCFE = free cash flow to equity, FCFD = free cash flow to debts, FCFW $=$ free cash flow to workers, FCFS $=$ free cash flow to suppliers, FCFM = free cash flow to municipal administration, FCFSt $=$ free cash flow to state.

For the groups presented above, the value distributed by the enterprise constitutes a benefit in the form of cash inflows, whereas for the company, it means an expended amount entailing a cost. For this reason, free cash flow to equity was estimated as a derivative of profit, depreciation, capital expenditure, demand for net working capital and principal instalments.

Cash flow to banks is the result of interest and principal instalments. Flows to employees arise from remuneration and other benefits paid to them. Free cash flow to suppliers results from the incurred costs of materials, energy and outsourced services. Cash flows to municipalities and local governments and to the state stem from taxes and fees paid to them as well as income tax [57].

In the presented formulas, the categories of revenues and costs were adjusted for the tax shield effect. At the same time, revenues and expenses were adjusted for the related receivables, payables and other liabilities. They are part of the broadly understood net working capital requirement.

Below, the mathematical calculation of the particular cash flows determined by the various kind of stakeholders is presented:

Free Cash Flow to Equity (FCFE): 
$(=)$ Earning after tax

$(+)$ Depreciation of tangible assets

(+) Amortisation of intangible assets

$( \pm$ ) Capital expenditure (Capex) combined with investment in fixed assets

$( \pm)$ Working capital requirement including inventories, receivables and payables

$( \pm)$ Principals of bank loans and other financial liabilities

\section{Free Cash Flow to Debts (FCFD):}

$( \pm)$ Principals of bank loans and other financial liabilities

$(+)$ Interests (1-Tax)

(+) Other financial payments to debt (1-Tax)

\section{Free Cash Flow to Workers (FCFW):}
(+) Gross Salaries (1-Tax)
(+) Employee insurance paid by employer
(+) Other Labour costs (1-Tax)
(+) Other employee benefits paid for workers (1-Tax)
$( \pm)$ Employee liabilities

\section{Free Cash Flow to Suppliers (FCFS):}
(+) Material costs (1-Tax)
(+) Energy cost (1-Tax)
(+) Outsourcing service Costs (1-Tax)
$( \pm)$ Receivables

\section{Free Cash Flow to Municipal Administration (FCFM):}
(+) Municipal taxes (1-Tax)
(+) Other municipal fees (1-Tax)
$( \pm)$ Municipal Liabilities

\section{Free Cash Flow to State (FCFSt):}

(+) Income corporate tax paid from gross profit

$( \pm)$ Tax liabilities

\section{Free Cash Flow from Value Added (FCF VA):}

$$
\text { FCFE + FCFD + FCFW + FCFS + FCFM + FCFSt }
$$

The methodology adopted in assessing value for all stakeholders, based on aggregating expenses by nature in the area of operating activities, is justified by the need to take a wider look at the total costs of business units' operation. It seems vital to adopt a wider perspective of the conducted business activities and take into consideration all the costs of the companies' operation, thus creating a sufficiently detailed stakeholder map [58]. A too general approach to costs in this area may result in obtaining incomplete information as regards the creation of real value for interest groups [57].

The methodology for estimating sustainable value consists in determining free cash flows to individual enterprise stakeholders during each of the analysed years in an ex-post perspective. Information on cash flows generated in a given period of time can be used to assess the company's achievements at a given moment in the past. Analysis of information on historical cash flows can also be a starting point in the process of making current and future decisions.

\section{Results}

This section verifies the pricing model of sustainable value distributed for stakeholders on the basis of the energy industry in Poland. Financial statements of the four largest energy companies in Poland, listed on the Warsaw Stock Exchange (WSE), were subjected to empirical research. The analysis encompasses energy sector groups established as a result of the consolidation of the Polish energy market under a government programme. The programme was aimed at creating economically strong enterprises that would be able 
to bear investment costs, compete and balance the energy market. The following companies were selected for verification: ENEA Group, ENERGA Group, PGE Group and TAURON Polish Energy.

The above enterprises are active in the pursuit of sustainable development, e.g., by way of the adopted social responsibility strategy and investing in renewables [59]. Active steps taken by the analysed entities in the areas of sustainable development resulted in their inclusion in the portfolio of socially responsible companies grouped in the Warsaw Stock Exchange Index- Environmental, Social, Governance (WIG-ESG index), launched on the Warsaw Stock Exchange on 3 September 2019 [60].

The research methodology, combining accrual and cash basis, made it possible to analyse the distribution of value created in the companies in the years 2009-2018. The research was based on data from their publicly available financial statements.

The starting point for the measurement of sustainable value for stakeholders was the determination of free cash flow from value added (FCF VA), i.e., the total value generated by the enterprises for their stakeholders in the years 2009-2018. Then, the shares of particular interest groups in the total value were established. In the following stage, cash flows typical of each interest group were verified, and reasons for changes in the process of shaping value were pointed out.

ENEA fulfils its potential to further increase electricity generation, while implementing environmental protection solutions and minimising the impact of the company's operations on the environment, along with an active dialogue with stakeholders [61]. The analysis for the Group shows the effects that were achieved thanks to joining forces and efforts towards creating universal value (Figure 2).

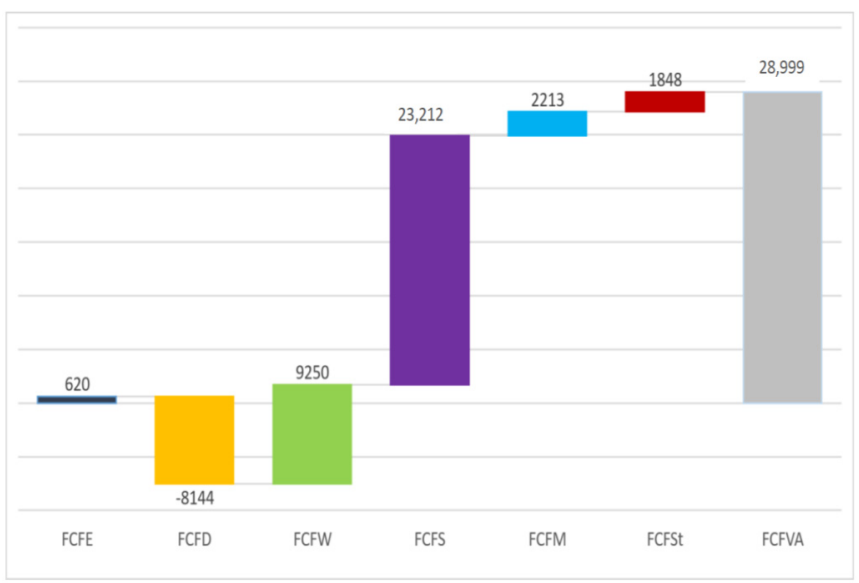

Figure 2. FCF VA and the shares of particular stakeholders in the total value generated by ENEA Group in the years 2009-2018 (PLN million). Source: own work based on Reference [62].

Suppliers have the largest share in the value generated by ENEA Group ( $80 \%)$. Employees are the second largest beneficiary of the company's value (32\%).

Free cash flow to banks shows negative values in the majority of the analysed years. In the above period, there was a negative balance in the banks' mutual relations with the company.

The share of local government units remained on average at 7.6\%. Payments to local government budgets in the form of taxes and fees transferred by the company fluctuated around PLN 2213 million annually.

The share of the state budget was at $6.4 \%$ during the analysed years. Every year, an average of PLN 1848 million is transferred to the state budget on account of income tax.

The owners were the smallest beneficiary of the value created in ENEA. Their share in the last ten years represents only about $2 \%$ of the total value.

In the years 2009-2018, the total value added generated by the company for its stakeholders, based on cash flow, amounted to PLN 28,999 million. 
In the case of ENERGA Group, the creation of shareholder value is pursued as the company's strategic goal, in parallel to the creation of value for other entities affected by its activities (Figure 3).

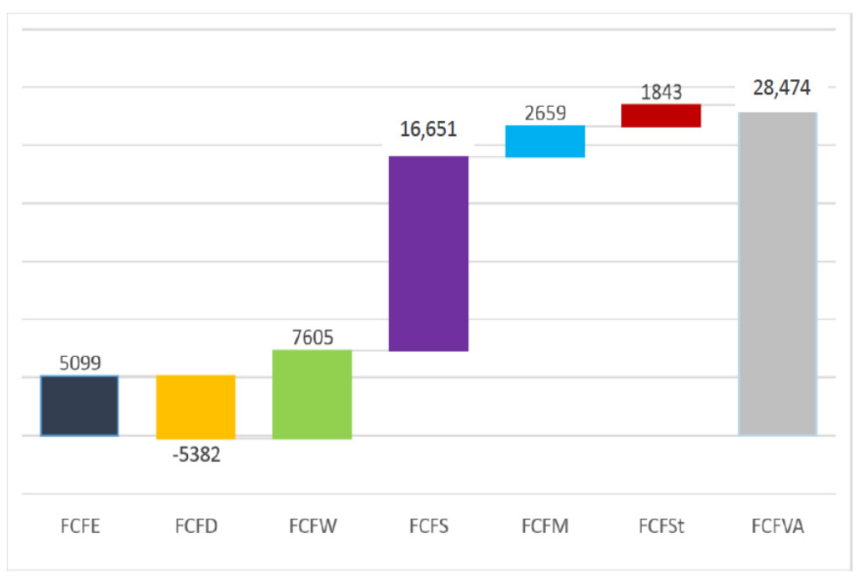

Figure 3. FCF VA and the shares of particular stakeholders in the total value generated by ENERGA Group in the years 2009-2018 (PLN million). Source: own work based on Reference [63].

Free cash flows to banks show negative values in their majority. In the covered period of time, capital providers did not benefit from mutual relations with the company.

The owners' share in the consumption of the value is at $18 \%$ on average, which amounts to about PLN 5099 million annually.

The share of local government units remains at $9.3 \%$ on average. Payments to local government budgets in the form of taxes and fees transferred by the company fluctuate around PLN 2659 million annually.

The share of the state budget during the analysed years is at $6.5 \%$, which means average receipts of PLN 1843 million.

In the years 2009-2018, the total value added generated by the company for its stakeholders, based on cash flow, amounted to PLN 28,474 million.

The mission of PGE Group is to increase the company's value for shareholders and to create its key role in ensuring the country's energy security [64]. Value for the Polish economy as well as for the enterprise, the environment and society are created in line with the conducted analysis. Figure 4 juxtaposes the assumptions and priorities in the Group's strategy for sustainable development tasks with actual problems that arise from the issues of creation and distribution of enterprise value to stakeholders.

Suppliers have the largest share in the value generated by PGE Group (41\%). Employees are the second largest beneficiary of the company's value (29\% of the total value).

Free cash flow to banks shows negative values in the majority of the analysed years. Banks provided cash to the company and drew financial benefits from interest on credit facilities and loans.

The share of local government units remains at around 18.6\%. Payments transferred by PGE to local government budgets in the form of taxes and fees amount, on average, to PLN 22,322 million annually.

The share of the state and of the owners during the analysed years is at the level of $7 \%$, which determines average budget receipts of PLN 8415 million per year and benefits for owners of about PLN 8393 million.

In the years 2009-2018, the total value added generated by the company for its stakeholders, based on cash flow, amounted to PLN 119,972 million. 


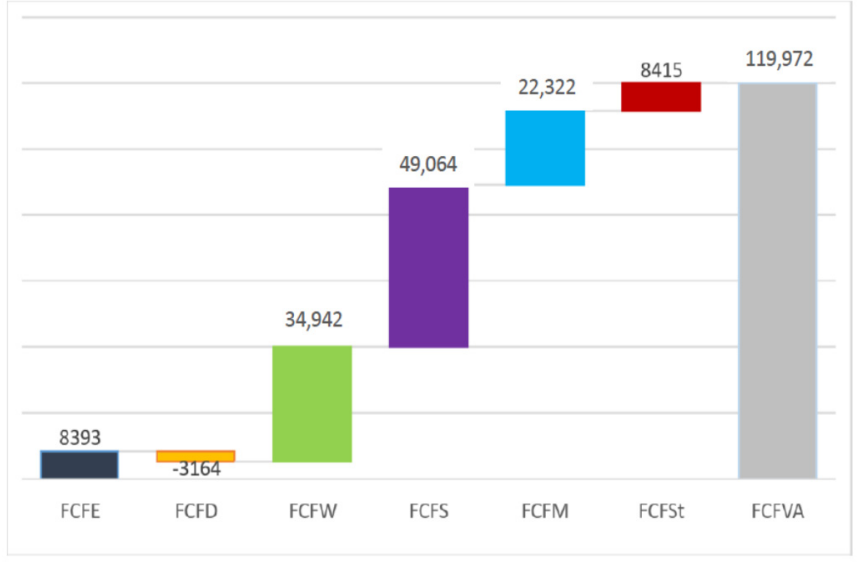

Figure 4. FCF VA and the shares of particular stakeholders in the total value generated by PGE Group in the years 2009-2018 (PLN million). Source: own work based on Reference [65].

Every year, TAURON Polish Energy maintains its obligation to report non-financial issues, in which a lot of emphasis has been placed on a transparent communication policy with numerous stakeholders. In response to the needs of a wide range of interests, the Group verifies its commitments and strategic directions, creating a sustainable value for the economy, enterprise and society [66], in line with the conducted analysis (Figure 5).

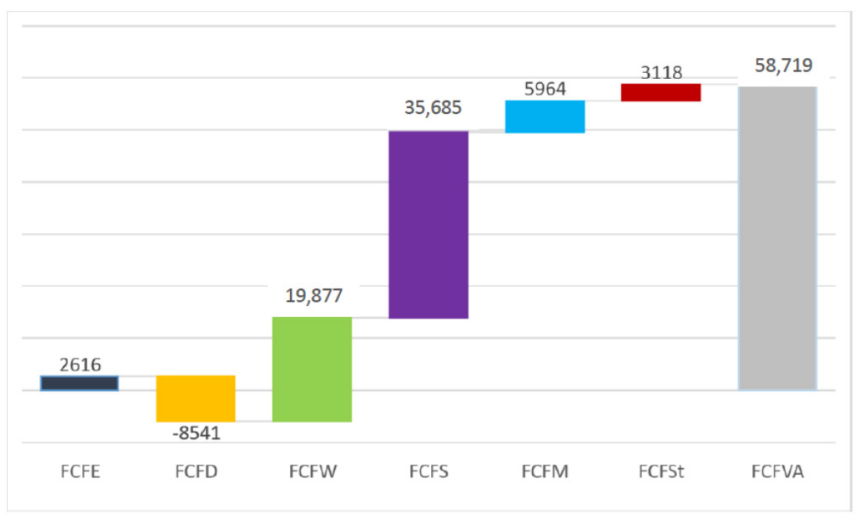

Figure 5. FCF VA and the shares of particular stakeholders in the total value generated by TAURON in the years 2009-2018 (PLN million). Source: own work based on Reference [67].

Suppliers have the largest share in the value generated by TAURON Polish Energy $(61 \%)$. Employees are the second largest beneficiary of the company's value (34\% of the total value).

Free cash flow to banks shows negative values in the majority of the analysed years, indicating the supply of cash to the company and obtaining financial benefits only through interest.

The share of local government units remains at around $10 \%$. Payments transferred by TAURON to local government budgets in the form of taxes and fees amount, on average, to PLN 5964 million annually.

The share of the state is at the level of $5 \%$, which determines average budget receipts of PLN 3118 million per year.

The owners' share in the consumption of value is at $4.5 \%$ on average, which amounts to about PLN 2616 million annually.

In the years 2009-2018, the total value added generated by the company for its stakeholders, based on cash flow, amounted to PLN 58,719 million. 


\section{Discussion}

This section has been split into two parts. The first part presents theoretical discussion about application of value added to company analysis and the impact of stakeholders together with literature analysis. The second one shows the cash flows for individual companies and its comparative analysis in the context of the model proposed in Section 2. At the same time, the FCF were diversified from the point of view of various interest groups, indicating which of the analysed business entities generates the highest value in a given type of flow.

5.1. Theoretical Discussion about Application of Value Added to Company Analysis and the Impact of Stakeholders

The concept of value added (VA) was used firstly in 1790 by Trench Cox to calculate gross domestic product (GDP). The macroeconomic origin indicates the significant economic importance of the added value: on the national scale, it is used to determine the share of a given enterprise in creating national income [68]. Ruggles and Ruggles [69] define added value as the difference between the market value of goods that have been donated by the company and the cost of those goods and materials purchased from other manufacturers. Under certain conditions, excluding the share of other entities in the total production value of a given enterprise, it can be assumed that value added determines the company's share in generating the national income.

In the literature, the added value is most often perceived in terms of the difference between the revenues from the sale of production and services and the expenditure incurred for their implementation (purchase of raw materials, materials, external services) [70,71]. This term quantifies the surplus of own labour, employee input, means of production over purchased materials and services. Therefore, it can be concluded that the resources used by the enterprise and shared by the enterprise's stakeholders are crucial. Properly managed financial resources (equity and external capital), human resources (employees), material resources (lands, buildings) and natural resources (fossil fuels, water, atmosphere) impact the formation of a surplus in the form of added value. Resources also include intangible elements, i.e., know-how, knowledge and experience of employees, social relations and good working conditions [72]. Due to the effective use of the above-mentioned elements, the value of the surplus is the value allocated to the division into shareholders, employees, the state budget, capital donors and other stakeholders.

Lozano-Platonoff [73] proposes a different approach. He defines the added value of the company as knowledge about the benefits expected by individual stakeholders of the company and the level of their fulfilment; that is, what (specific) effects should the company generate to satisfy various groups of stakeholders and to what extent it achieves them. The concept of VA is based on economic, social and environmental effectiveness, and thus it constitutes a special measure of the level of meeting the material and nonmaterial needs of individual stakeholders of the enterprise. This fact implies the view that a company's added value determines the total return for all interested groups, in line with the recommendations of sustainable development. It consists of the added value of the company shared also between the society, customers, employees of lower, middle and high level, etc. The goal of the company, which is to generate value for the owners, is in this case the same as the expectations of other stakeholders of the company.

The concept of added value gained special significance when the Accounting Standards Steering Committee (ASSC) published the Corporate report. The aim of this was to promote the value-added report, showing how the benefits of the company's operations are shared among employees, the treasury, reinvestments and capital donors [74].

The necessity of supplement classic financial and non-financial statements with elements of the value-added report was noted, among others, by Morley [75] or Luis PereraAldama [76], the creator of the methodology known as the "fourth financial report" for the energy industry. In their presented proposals, the social dimension of business activity is shown. In addition to scientific concepts based on added value, the contemporary business 
reality, meeting market requirements, also creates tools and mechanisms that promote the concept of creating company value in accordance with sustainable development [77-80].

Literature and the business environment show that there are many methods which measure added value and social wealth as well. However, in most cases, authors use data from previous periods, which does not explain the reasons for their changes. Although the retrospective approach is a complementary source of knowledge about the achievements of the enterprise, only the recognition of factors influencing the changes in the level of specific variables can be of a decision-making nature. Additionally, all identified value creation concepts are based on revenues and costs typical of the accrual approach. This fact prompted the authors of the publication to attempt to fill the described research gap. The approach presented in this article is based not on accrual results, but on cash flows characteristic of receipts and expenditures. The approach from the side of liquidity and not profitability is new in relation to the analyses carried out so far.

5.2. Comparative Analysis in the Context of the Proposed Value-Added Model in the Example of the top Polish Energy Company

The comparison of the total value (FCF VA) created and intended for distribution to the selected stakeholders is presented in Figure 6.

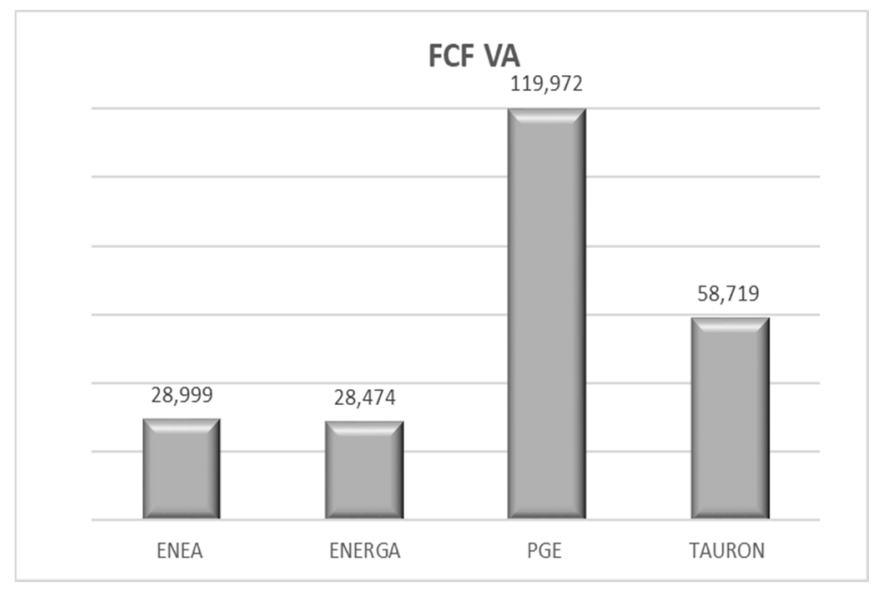

Figure 6. Free cash flow from value added in the years 2009-2018 (PLN million). Source: own work based on References [62,63,65,67].

In the years 2009-2018, the energy industry realised a total of PLN 236,164 million for the selected interest groups. PGE was the leader in generating cash flows, having created over four times greater value than ENEA and ENERGA and twice as much cash flow as TAURON Polish Energy. The value generated was dependent on numerous factors: some of them were determined by the size of the enterprise, determined based on its financial data and the number of employees. On the other hand, distribution of value was contingent on the companies' financial position, yet not only. To a large extent, it was accounted for by relevant management decisions determining distribution of the generated funds for the purposes of further investments and current consumption.

Figures 7-12 present the development of financial flows to particular stakeholders having their share in the total value generated by the analysed enterprises in the years 2009-2018. 


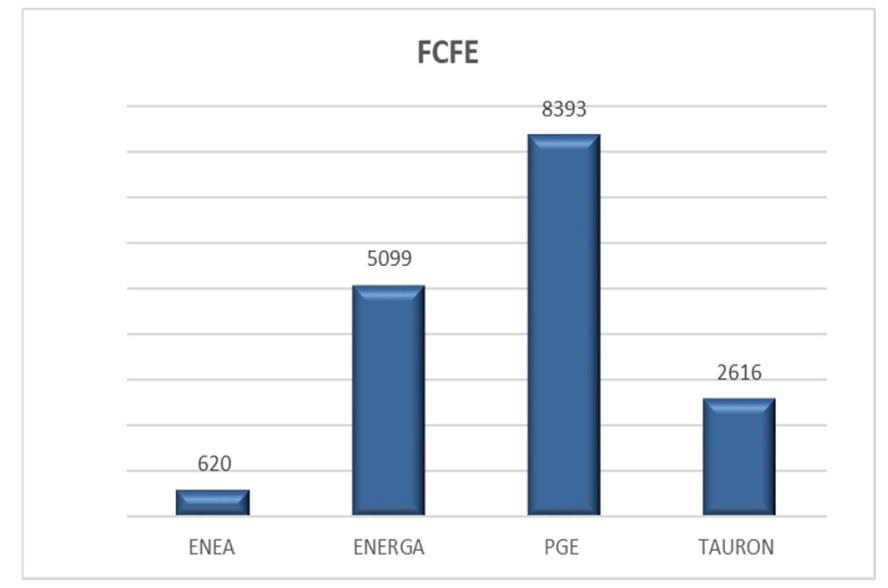

Figure 7. Free cash flow to equity (FCFE) in the years 2009-2018 (PLN million). Source: own work based on References [62,63,65,67].

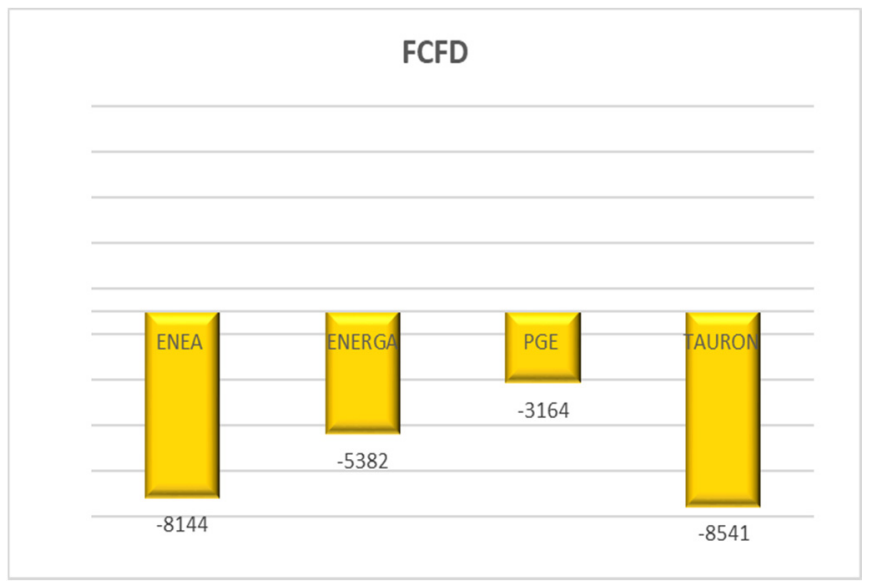

Figure 8. Free cash flow to equity (FCFD) in the years 2009-2018 (PLN million). Source: own work based on References $[62,63,65,67]$.

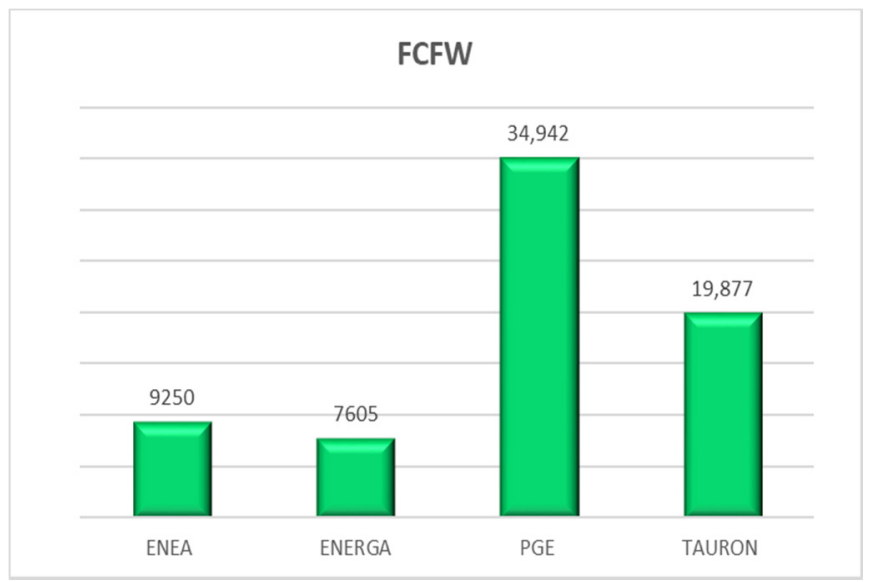

Figure 9. Free cash flow to workers (FCFW) in the years 2009-2018 (PLN million). Source: own work based on References $[62,63,65,67]$. 


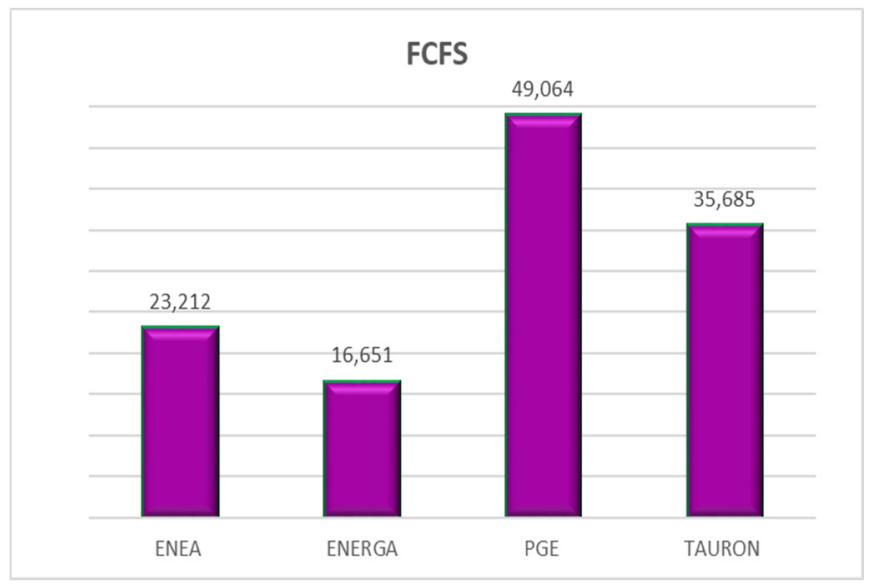

Figure 10. Free cash flow to suppliers (FCFS) in the years 2009-2018 (PLN million). Source: own work based on References $[62,63,65,67]$.

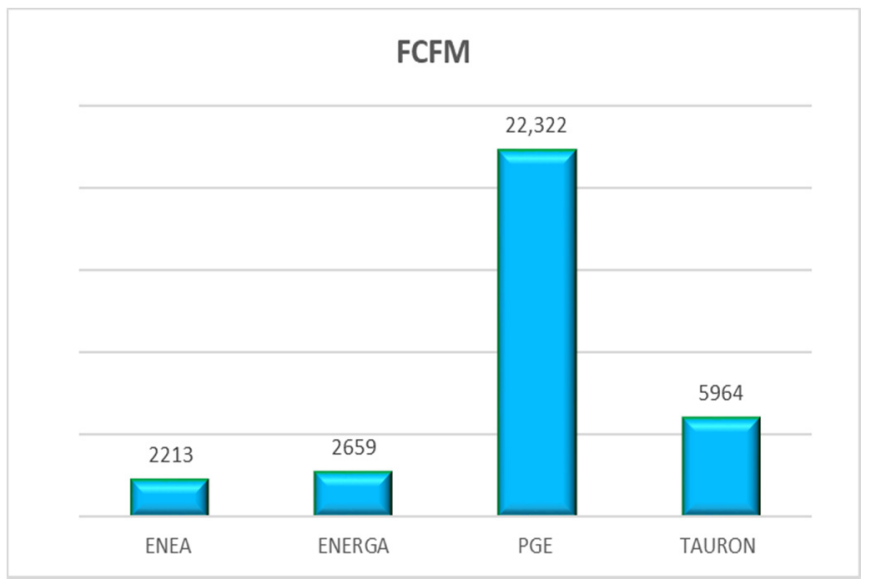

Figure 11. Free cash flow to municipalities (FCFM) in the years 2009-2018 (PLN million). Source: own work based on References [62,63,65,67].

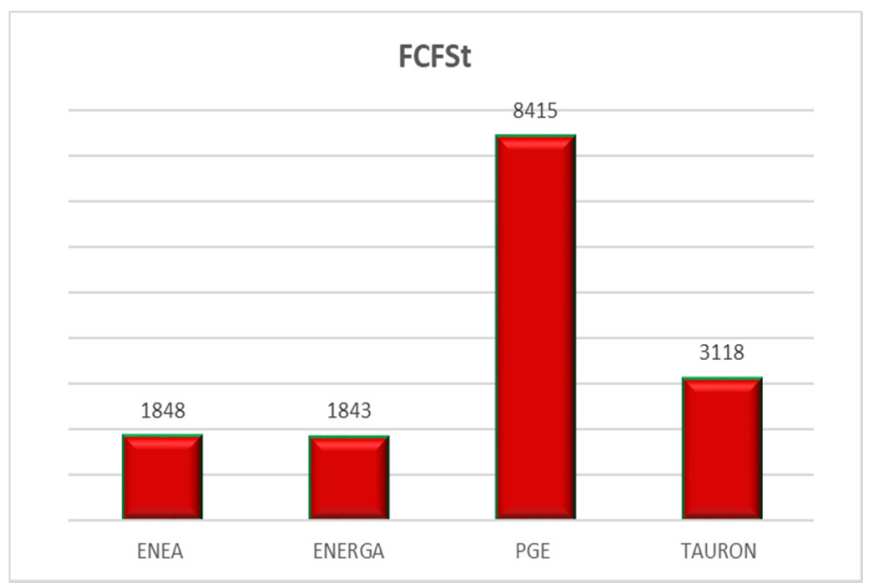

Figure 12. Free cash flow to state (FCFS) in the years 2009-2018 (PLN million). Source: own work based on References [62,63,65,67].

An analysis of the researched enterprises in terms of the possibility of creating value for their shareholders (Figure 7) indicates that during the ten analysed years, the energy industry brought benefits of over PLN 16,728 million to the companies' owners. PGE was 
the largest generator of profits for the owners (over $50 \%$ of the total value). In the course of its production, commercial and service activities, it realised over PLN 8393 million for this interest group in the years 2009-2018.

The total value generated for banks is negative (Figure 8). Capital providers are an unquestioned example of an interest group that, in the indicated time period, supplied energy companies with the highest value of capital to be allocated for investments and current operations, drawing benefits only through interest paid to them. A high percentage of loans and credit facilities granted by banks to the energy sector resulted in the amount of debt of over PLN 25 million. Negative benefits for this interest group are the result of a cash flow-based mechanism.

Intellectual capital is a significant element in the process of value creation (Figure 9). As the industry experience shows, employees are one of the main beneficiaries of the generated surplus. The energy sector demonstrates a strong focus on employees, whose remuneration and benefits in the years 2009-2018 totalled over PLN 71,674 million. The value generated at PGE (49\%) had the greatest impact. This enterprise is in the top three most desirable employers in the area of energy, fuel and mining. Technological progress is of key importance for the development of the fuel and energy sector, and it is already changing the way in which this industry is perceived. Due to the development of the companies' operations, both employment and the level of remuneration are on a steady rise year by year.

The analysed value distribution process results in the fact that the group most closely associated with the energy sector is the group of suppliers (Figure 10). They receive the greatest financial benefits from the companies (over PLN 124,612 million in total) and gain the most from mutual relations with these enterprises. PGE, which realised 39\% of the total value for its contractors, is the leader in providing cash flows to suppliers of goods and services.

Comparing the analysed entities through the prism of the scope of activity, the main creator of added value for local government budgets was PGE (Figure 11), which paid a total of less than PLN 22,322 million to the budgets of local governments via various forms of taxation: from personal income tax for its employees, through Corporate Income Tax (CIT), to excise and other taxes, which constitutes $67 \%$ of the total value for local governments. As a result, according to public rankings, the company became the largest remitter of taxes in Poland in the last of the analysed years. In the years 2009-2018, the indicated energy companies supplied local governments with over PLN 33,158 million.

The distribution of value to the State Treasury indicates that PGE Group was the largest payer of income tax, creating a total of over $55 \%$ of the value (Figure 12). It is worth emphasising that payments to the budget in the last year increased by almost $8 \%$, even though the profit fell by $42 \%$ year-on-year. In total, the energy industry supplied the State Treasury with over PLN 15,224 million in the years 2009-2018.

The model for measuring sustainable value for energy company stakeholders makes it possible to identify interest groups that would have suffered most in the recent period in case incorrect decisions had been made at management levels as to the discontinuation of business activity. According to the analysis carried out, these would have been the following (from the most involved to the ones with the lowest contribution): suppliers of goods and services, employees and local governments, owners, the state budget and capital providers.

The analysis of value distribution in the energy industry unequivocally demonstrates a significant contribution of the sector to creating value for the companies' environment and the economy. Providing jobs, a steadily increasing level of employment and remuneration, maintaining proper relations with business partners giving rise to long-term contracts with suppliers of goods and services and settling the obligatory charges on the financial result (i.e., interest or taxes) are just a few of the many steps intended to ensure prosperity and economic growth of the country taken by the fuel and energy industry. 
All attempted steps towards the sustainable development of industry also contribute to an increase in the trust and loyalty of the customers of the enterprises, which, as listed companies, are obliged to fulfil their disclosure requirements. Hence, it is particularly important to ensure transparency in relations with stakeholders, since it contributes to the creation of a positive image of the entire energy industry.

\section{Conclusions}

The analysis conducted as part of this paper, based on the energy industry, explains the contribution of the researched enterprises to creating private and public revenues and illustrates how these companies' business activity creates value for the enterprise, the economy and society.

The results presented above support the idea of stressing the financial effects of the operations of fuel and energy sector companies in terms of building positive relations with stakeholders, which, at the same time, encourages these enterprises to lay stress on the implementation of sustainable development policy in their strategy.

The presented model for measuring sustainable value in the fuel and energy industry highlights the fact that the value created in the enterprise is a derivative of joint efforts of various stakeholders cooperating with the enterprises. At the same time, the proposed solution reveals how the effects brought by the joint efforts are distributed to particular recipients of value.

The assessment of the analysed enterprises in terms of their ability to generate added value leads to the conclusion that each of the presented interest groups has its own, larger or smaller share in the consumption of value, thus drawing on mutual relations with the companies.

In the years 2009-2018, the analysed energy companies realised a total of PLN 236,164 million for their close and remote environment. PGE Group had the largest, $51 \%$ contribution to the total value, reaching the highest FCF VA values, which amounted to more than PLN 119,972 million.

The financial statements of the analysed enterprises for particular years demonstrate certain problems related to a temporary lack of profitability. This situation occurred in ENEA, PGE and TAURON in 2015. Nevertheless, recording a net loss on operations did not prevent the companies from meeting their owners' and other stakeholders' expectations in the form of remuneration and benefits, interest on loans and credit facilities, taxes and fees, income tax and profits for suppliers. Despite the temporary lack of profitability, the companies brought specific benefits to society. Communication policy based on a transparent dialogue with stakeholders is supported by the development of social activities that encompass preservation of jobs and supporting local groups associated with the enterprises.

As indicated by the financial data and the research based on them, Polish practices in the field of sustainable value creation are very successful. Based on the attempted numerical presentation of the energy sector's contribution to the country's economic situation, it was possible to observe the multitude of financial benefits it distributes to society. These financial benefits could potentially be lost-in case fuel and energy companies ceased to operate-or reduced, if there was a decline in their performance.

The research presented in the paper is based on data from financial reporting. This is a limitation of the research and some simplifications have to be made, as more complete data could be obtained from the management accounting system and management reporting. However, these systems are intended to making decisions for management staff and they collect information on a multidimensional basis and allow to filter data according to specific needs and requirements.

As it is known, management reporting and its information are not distributed outside the company, because they constitute sensitive data, often being key performance indicators to the company on the commercial market.

In the future, it should be expected that a wider range of data for the purposes of analyses, similar to those presented in the article, should be obtained from integrated reporting. It 
includes both financial reporting from financial and management accounting as well as reporting in the area of multidimensional corporate social responsibility related to reporting according to ESG (Environment, Social, Governance) or GRI (Global Reporting Initiative).

Author Contributions: Conceptualisation and methodology S.L. and A.K.; data analysis in the software S.L.; validation S.L. and A.K.; formal analysis S.L. and A.K.; investigation S.L. and A.K.; resources S.L.; data curation S.L.; writing-original draft preparation S.L.; writing-review and editing S.L.; visualisation S.L. and A.K.; supervision S.L. and A.K.; project administration S.L. and A.K.; funding acquisition S.L. and A.K. All authors have read and agreed to the published version of the manuscript.

Funding: Research results presented in this paper are an element of the statutory research 16.16.100.215.

Institutional Review Board Statement: Not applicable.

Informed Consent Statement: Not applicable.

Data Availability Statement: The financial data used in the article were taken from the financial statements of the analysed enterprises for the years 2009-2018.

Conflicts of Interest: The authors declare no conflict of interest.

\section{References}

1. European Environmental Agency. Climate Change, Impacts and Vulnerability in Europe 2012: An Indicator-Based Report; European Environmental Agency: Copenhagen, Denmark, 2012.

2. Martinez, M.G. Co-creation of Value by Open Innovation: Unlocking New Sources of Competitive Advantage. Agribusiness 2014, 30, 132-147. [CrossRef]

3. Jackson, S.E.; Hitt, M.A.; DeNisi, A.S. Managing Knowledge for Sustained Competitive Advantage; Jossey-Bass: San Francisco, CA, USA, 2003; pp. 40-44, 64-65.

4. Foss, N.J.; Pedersen, T.; Pyndt, J. Innovating Organization and Management; Cambridge University Press: Cambridge, MA, USA, 2012; pp. 208-213.

5. Freeman, R.E. Strategic Management: A Stakeholder Approach; Pitman Press: Boston, MA, USA, 1984.

6. Huggins, R.; Izushi, H. Competition, Competitive Advantage, and Clusters: The Ideas of Michael Porter; Oxford University Press: Oxford, UK, 2012.

7. Schaltegger, S.; Bennett, M.; Burrit, R. Sustainability Accounting and Reporting; Springer: Dordrecht, The Netherlands, 2006; pp. 61-68.

8. PWC. Measuring total impact: A new language for business decisions PwC, UK, May 2013. Available online: https://www.post2 020hlp.org/wp-content/uploads/docs/PwC_Measuring-total-impact-A-new-language-for-business-decisions.pdf (accessed on 10 December 2020).

9. EY. Corporate Responsibility Report 2019-2020, The Netherlands. 2020. Available online: https://assets.ey.com/content/dam/ ey-sites / ey-com/nl_nl/topics / corporate-responsibility/cr-reports /2019-2020/ey-corporate-responsibility-report-2019-2020en-v1.pdf (accessed on 12 December 2020).

10. Copeland, T.; Koller, T.; Murrin, J. Valuation: Measuring and Managing the Value of Companies, 3rd ed.; John Wiley \& Sons, Inc.: New York, NY, USA, 2000.

11. Nukala, V.; Luthra, P. Models for measuring and predicting shareholder value: A study of third party software service providers. Sadhana 2005, 30, 475-498.

12. Mekonnen, M.M.; Turner, R. Adding Shareholder Value through Project Performance Measurement, Monitoring \& Control: A critical review. ERIM Rep. Ser. Res. Manag. 2002, 38, 1-17.

13. Niki, L. Performance Measurement: A Stakeholder Approach. Sinergi 2008, 10, 179-198.

14. Kotane, I. Use of financial and non-financial indicators in evaluation of company's performance. In CBU International Conference Proceedings; ISE Research Institute, 2015; Volume 3, pp. 224-233. Available online: https:/ / ojs.journals.cz/index.php/CBUIC/ issue/view/65 (accessed on 10 December 2020). [CrossRef]

15. Kujala, J.; Lehtimäki, H.; Freeman, R.E. A Stakeholder Approach to Value Creation and Leadership. In Leading Change in a Complex World; Kangas, A., Kujala, J., Heikkinen, A., Lönnqvist, A., Laihonen, H., Bethwaite, J., Eds.; Tampere University Press: Tampere, Finland, 2019; pp. 123-143.

16. Hering, T. Der Entscheidungswert bei der Fusion. Betriebswirtschaftliche Forschung und Praxis 2004, 2, 148-165.

17. Koller, T.; Geodhart, M.; Wessels, D. Valuation: Measuring and Managing the Value of Companies, 5th ed.; John Wiley \& Sons, Inc.: Hoboken, NJ, USA, 2010.

18. Pimonenko, T.; Bilan, Y.; Horák, J.; Starchenko, L.; Gajda, W. Green brand of companies and greenwashing under sustainable development goals. Sustainability 2020, 12, 1679. [CrossRef]

19. Hart, S.L.; Milstein, M.B. Creating sustainable value. Acad. Manag. Perspect. 2003, 17, 2. [CrossRef] 
20. The MBA Oath. Available online: https://mbaoath.org/ (accessed on 23 October 2020).

21. Parmar, B.L.; Freeman, R.E.; Harrison, J.S.; Wicks, A.C.; Purnell, L.; De Colle, S. Stakeholder Theory. The State of the Art. Acad. Manag. Perspect. 2017, 4, 403-445.

22. Silbert, T.H. Financing and factoring accounts receivable. Harv. Bus. Rev. 1952, 30, 39-54.

23. Scherer, A.G.; Patzer, M. Where is the theory in stakeholder theory? A meta-analysis of the pluralism in stakeholder theory. In Stakeholder Theory: Impact and Prospects; Phillips, R.A., Ed.; Edward Elgar Publishing: Cheltenham, UK, $2011 ;$ pp. 140-162.

24. Post, J.E.; Preston, L.E.; Sachs, S. Redefining the Corporation. Stakeholder Management and Organizational Wealth; Stanford Business Books: California, CA, USA, 2002.

25. Wheeler, D.; Sillanpää, M. The Stakeholder Corporation, A Blueprint for Maximizing Stakeholder Value; Pitman Publishing: London, UK, 1997.

26. Zakhem, A.J.; Palmer, D.E.; Stoll, M.L. Stakeholder Theory. Essential Readings in Ethical Leadership and Management; Prometheus Books: New York, NY, USA, 2008.

27. Nalewaik, A. Stakeholder Expectations Regarding Public Project Oversight. In Proceedings of the 25th IPMA World Congress: Project Management-Delivering the Promise, Brisbane, Australia, 9-12 October 2011.

28. Marcinkowska, M. Creating company value for stakeholders. Zeszyty Naukowe Uniwersytetu Szczecińskiego 2011, 7, 855-869.

29. Darškuvienè, V.; Bendoraitienė, E. Stakeholder expectations and influence on company decisions. Taikomoji Ekonomika: Sisteminiai Tyrimai 2014, 8, 83-96. [CrossRef]

30. Vandewalle, D.; Van Dyne, L.; Kostova, T. Psychological ownership: An empirical examination of its consequences. Group Organ. Manag. 1995, 20, 210-226. [CrossRef]

31. Harrison, J.S.; Wicks, A. Stakeholder Theory, Value, and Firm Performance. Bus. Ethics Q. 2013, 23, 97-124. [CrossRef]

32. Olkkonen, L. Stakeholder Expectations_Conceptual Foundations and Empirical Analysis; Jyvaskyla Studies in Humanities: Jyväskylä, Finland, 2015; pp. 44-51.

33. Theodor, M. A Stakeholder Approach to Measuring the Level of Corporate Governance. EIASM Workshop on Corporate Governance; EIASM: Brussels, Belgium, 2004.

34. Skouloudis, A.; Avlonitis, G.J.; Malesios, C.; Evangelinos, K. Priorities and perceptions of corporate social responsibility: Insights from the perspective of Greek business professionals. Manag. Decis. 2013, 53, 375-401. [CrossRef]

35. Milne, M.J.; Gray, R. W(h)ither ecology? The triple bottom line, the global reporting initiative, and corporate sustainability reporting. J. Bus. Ethics 2013, 118, 13-29. [CrossRef]

36. Okanga, B.; Groenewald, D. Leveraging effects of triple bottom lines business model on the building and construction small and medium-sized enterprises' market performance. Acta Commercii 2017, 17, 1-14. [CrossRef]

37. Harrison, J.S.; Bosse, D.A.; Phillips, R.A. Managing for stakeholders, stakeholder utility functions and competitive advantage. Strateg. Manag. J. 2010, 31, 58-74. [CrossRef]

38. Jones, T.M.; Wicks, A.C. Convergent stakeholder theory. Acad. Manag. 1999, 24, 206-221.

39. Popescu, C.R.; Popescu, G.N. An Exploratory Study Based on a Questionnaire Concerning Green and Sustainable Finance, Corporate Social Responsibility, and Performance: Evidence from the Romanian Business Environment. J. Risk Financ. Manag. 2019, 12, 162. [CrossRef]

40. OECD. China in a Changing Global Environment. Available online: https://www.oecd.org/china/china-in-a-changing-globalenvironment_EN.pdf (accessed on 4 February 2020).

41. Swora, M.; Kamiński, J. Bringing in liquidity and transparency when the power sector is consolidated: The duty to trade on the power exchange. Rev. Econ. Inst. 2017, 8, 1-29. [CrossRef]

42. Suwala, W. Modelling adaptation of the coal industry to sustainability conditions. Energy 2008, 33, 1015-1026. [CrossRef]

43. Bluszcz, A.; Manowska, A. Differentiation of the level of sustainable development of energy markets in the European Union countries. Energies 2020, 13, 4882. [CrossRef]

44. Bradbrook, J.; Hemmersbach, R.; Lebert, M.; Ottinger, R.; Wang, X. The Law of Energy for Sustainable Development; Cambridge University Press: New York, NY, USA, 2005.

45. Kanagawa, M.; Nakata, T. Assessment of access to electricity and the socio-economic impacts in rural areas of developing countries. Energy Policy 2008, 36, 2016-2029. [CrossRef]

46. Meyar-Naimi, H.; Vaez-Zadeh, S. Sustainable development based energy policy making frameworks, a critical review. Energy Policy 2012, 43, 351-361. [CrossRef]

47. Wang, X.; Nathwani, J.; Wu, C. Visualization of International Energy Policy Research. Energies 2016, 9, 72. [CrossRef]

48. Tiba, S.; Omri, A. Literature survey on the relationships between energy, environment and economic growth. Renew. Sustain. Energy Rev. 2017, 69, 1129-1146. [CrossRef]

49. Yudha, S.W.; Tjahjono, B. Stakeholder Mapping and Analysis of the Renewable Energy Industry in Indonesia. Energies 2019, 12, 602. [CrossRef]

50. Lorenc, S.; Sorokina, O. Sustainable development of mining enterprises as a strategic direction of growth of value for stakeholders. Min. Sci. 2015, 22, 67-78.

51. Gawlik, L.; Mokrzycki, E. Changes in the Structure of Electricity Generation in Poland in View of the EU Climate Package. Energies 2019, 12, 3323. [CrossRef] 
52. State raw material policy, Project of the Ministry of the Environment, Warsaw 2019. Available online: http://psp.mos.gov.pl/ images/pdf/PSP_projekt.pdf (accessed on 9 October 2020).

53. Mielcarz, P.; Mlinari ${ }^{` c}$, F. The superiority of FCFF over EVA and FCFE in capital budgeting. Economic Research-Ekonomska Istraživanja 2014, 27, 559-572. [CrossRef]

54. Dagnino, G.B.; Giachetti, C.; La Rocca, M.; Picone, P.M. Behind the curtain of international diversification: An agency theory perspective. Glob. Strategy J. 2019, 9, 555-594. [CrossRef]

55. Suhanda, N.H.; Hidayat, A.N.; Firmansyah, A. Firm value and performances in merger policy: Evidence from Indonesia. Acad. Account. Financ. Stud. J. 2019, 23, 1-12.

56. Georgios, P.N.; Chris, G. Employing valuation tools for public and private companies. The food sector in Greece. Procedia Econ Financ. 2015, 33, 491-505. [CrossRef]

57. Lorenc, S.; Kustra, A. Comparative analysis of sustainable value distribution for stakeholders in the mining industry. E3S Web Conf. 2018, 29, 1-13. Available online: https://www.e3s-conferences.org/articles/e3sconf/abs/2018/04/e3sconf_cpsys2018_00 013/e3sconf_cpsys2018_00013.html (accessed on 4 November 2020). [CrossRef]

58. Freeman, R.E.; Harrison, J.S.; Wicks, A.C. Managing for Stakeholders: Survival, Reputation, and Success; Yale University Press: London, UK, 2007.

59. Flanders Investment \& Trade Market Survey, Renevable Energy in Poland, Market Study, Poznań, June 2019. Available online: https:/ / www.flandersinvestmentandtrade.com/export/sites/trade/files/market_studies/2019-Poland-Renewable_ Energy.pdf (accessed on 3 November 2020).

60. GPW. The change of WIG-ESG methodology, Consultation Paper, Warsaw, July 2020. Available online: https://gpwbenchmark. pl/pub/BENCHMARK/files/PDF/komunikaty/Consultation_Paper_WIG-ESG.pdf (accessed on 3 December 2020).

61. Sustainable development Report of the ENEA Group for 2019, Relations with the socio-economic environment, Poznan 2020. Available online: https:/ / raport2019.csr.enea.pl/en/relacje-z-otoczeniem/komunikacja-z-interesariuszami/ (accessed on 14 December 2020).

62. Financial statements of ENEA Group for the years 2009-2018. Available online: https://ir.enea.pl/lista-raportow/kategoria/36 12 /raporty-okresowe (accessed on 10 September 2020).

63. Financial statements of ENERGA Group for the years 2009-2018. Available online: https://ir.energa.pl/pl/releases/4437 (accessed on 10 September 2020).

64. PGE Group Integrated Report. 2017. Available online: https://raportzintegrowany2017.gkpge.pl/en.html\#misja-i-wizja (accessed on 11 December 2020).

65. Financial statements of PGE Group for the years 2009-2018. Available online: https://www.gkpge.pl/relacje-inwestorskie/ Materialy-do-pobrania (accessed on 10 September 2020).

66. TAURON Integrated Report. 2019. Available online: https://en.raport.tauron.pl/ (accessed on 10 December 2020).

67. Financial statements of TAURON for the years 2009-2018. Available online: https:/ / www.tauron.pl/tauron/relacje-inwestorskie/ raporty-okresowe (accessed on 10 September 2020).

68. Hartley, W.C.F. An Introduction to Business Accounting for Managers, 4th ed.; Pergamon Press: Oxford, UK, 1987.

69. Ruggles, R.; Ruggles, N.D. National Income Accounts and Income Analysis, 2nd ed.; McGraw-Hill: New York, NY, USA, 1956.

70. Suojanen, W.W. Accounting theory and the large corporation. Account. Rev. 1954, 29, 391-398.

71. Van Staden, C.J. The usefulness of the value added statement in South Africa. Manag. Financ. 1998, 24, 337-351. [CrossRef]

72. Bluszcz, A.; Kijewska, A.; Sojda, A. Generowanie wartości dodanej dla interesariuszy przez spółkę górniczą. In Nowoczesność przemystu $i$ ustug w warunkach kryzysu i nowych wyzwań; Brzóska, J., Pyka, J., Eds.; Towarzystwo Naukowe Organizacji i Kierownictwa: Katowice, Poland, 2013; pp. 461-471.

73. Lozano Platonoff, A. Zarzadzanie dynamiczne. Nowe podejście do zarzadzania przedsiębiorstwem; Difin: Warsaw, Poland, 2009.

74. Riahi-Belkaouri, A. Value Added Reporting_Lessons for the United States; Quorum Books: New York, NY, USA, 1992.

75. Morley, M.F. The value added statement in Britain. Account. Rev. 1979, 54, 618-629.

76. ISAGEN SAE.S.P. Management Report 2017-Distribution of value to stakeholders. Available online: https://www. unglobalcompact.org/participation/report/cop/create-and-submit/advanced/416632 (accessed on 2 February 2020).

77. EY. Available online: https://www.ey.com/pl_pl/corporate-responsibility (accessed on 1 February 2020).

78. Deloitte, 2017, CSR action and engagement in the workplace. Available online: https://www2.deloitte.com/content/dam/ Deloitte/us/Documents/human-capital/us-cons-engaging-the-workforce.pdf (accessed on 10 August 2020).

79. KPMG. Available online: https://home.kpmg/lu/en/home/about/corporate-social-responsibility.html (accessed on 1 February 2020).

80. PWC Report 2017, Measuring and Managing Total Impact—Strengthening Business Decisions for Business Leaders. Available online: https://www.pwc.com/gx/en/services/sustainability/total-impact-measurement-management/measuring-andmanaging-total-impact-strengthening-business-decisions-for-business-leaders-food-and-beverage-scenario.html (accessed on 25 January 2020). 